\title{
Effect of Micro Nutrient Deficiency on Yield and Performance of Sweet Orange (Citrus sinensis) in Nalgonda District, Telangana, India
}

\author{
Kola Shailaja ${ }^{1^{*}}$ and B. Murali ${ }^{2}$ \\ ${ }^{1}$ AICRP on Forage Crops \& Utilization Agricultural Research Institute, \\ Rajendranagar, Hyderabad, India \\ ${ }^{2}$ Professor Jayashankar Telangana State Agricultural University, \\ Hyderabad, Telangana, India \\ *Corresponding author
}

\section{Keywords}

Sweet orange,

Yield, Micro

nutrients,

Deficiency,

Nalgonda,

Telangana, India

Article Info

Accepted:

15 March 2020

Available Online:

10 April 2020

A B S T R A C T

The present investigation was conducted in order to improve the yields of Sweet Orange in Nalgonda district of Telangana. In India, Telangana is one of the major sweet orange producing states. Sweet Orange is major important horticulture crop which was having high source of vitamin C. Farmers are getting lower yields due to non adoption of proper management practices, neglecting the application of micronutrients, due to this reason most of the farmers facing micronutrient deficiency in Sweet Orange of Nalgonda District in Telangana. In order to reduce micronutrients deficiency and improve yields, OFT was conducted in farmers' field in two years with three locations in each year. Timely application of micronutrients to Sweet Orange improve the yields and B:C ratio in OFT, when compared to farmer practice. The average yield and $\mathrm{B}: \mathrm{C}$ ratio of three farmers in 2016-17 was $7600 \mathrm{~kg} / \mathrm{ac}$ and 1.8:1 in farmer practice, where as in OFT average yield and B:C ratio was improved to $9800 \mathrm{~kg} / \mathrm{ac}$ and 2.6:1 respectively. In 2017 18 average yield and $\mathrm{B}: \mathrm{C}$ ratio was $9560 \mathrm{~kg} / \mathrm{ac}$ and 5.86:1 in OFT compared to farmer practice was $7840 \mathrm{~kg} / \mathrm{ac}$ and $4.45: 1$ yield and $\mathrm{B}: \mathrm{C}$ ratio respectively. Application of micronutrients improves the yield and quality of fruit.

\section{Introduction}

Sweet Orange (Citrus sinensis) belonging to the family Rutaceae Deep well drained loamy soils are the best for the cultivation of Citrus. $\mathrm{pH}$ of soil should be 6.5 to 7.5. Nalgonda soils are suitable for cultivation of Sweet Orange. In India, Telangana state was in fourth position in productivity $14.89 \mathrm{MT} / \mathrm{ha}$ during 2017-18 after Andhra Pradesh, Madhya Pradesh and Karnataka. The major Sweet orange (Citrus sinensis) growing states in India are Telangana, Andhra Pradesh, Maharashtra, Madhya Pradesh, Karnataka, Punjab, Bihar, Assam, Mizoram and Jammu \& Kashmir. 
Etebu and Nwauzoma (2014) reported that diseases can be controlled in sweet orange through chemical treatment of fruits, use of biological control agents, proper packaging and storage facilities and other disease management practices to reduce post harvest damages. Deficiency of micronutrients ( $\mathrm{Zn}$, $\mathrm{Cu}, \mathrm{Fe}$, and $\mathrm{Mn}$ ) in the soil of citrus orchards also affects the fruit yield and quality reported by Ibrahim et al., (2007), Ashraf et al., (2012). Different workers suggested that application of suitable combination of plant growth regulators, macro and micronutrients can control the excessive fruit drop and improve the yield and quality of citrus fruit by Doberman and Fairhurst (2000), Rodriguez et al., (2005), Saleem et al., (2005). Shradha Neware et al., (2015) proved that the effectiveness of micro nutrient and growth regulators in increasing yield and quality of sweet orange.

Therefore, effective supply of micronutrients is necessary to produce high yield with quality citrus fruits. The present Investigation was carried out in order to reduce the losses and improve the yields of sweet orange in Nalgonda district of Teleangana state in India. Most of the farmers in Nalgonda district were growing Sweet Orange. The farmers' yields are decreasing due to non adoption of proper management practices in respective application of micronutrient. The farmers are neglecting the spraying in timely application of micronutrients to sweet orange. So the present investigation was carried out on Effect of Micronutrients Deficiency on Yield and Performance of Sweet Orange (Citrus sinensis) in farmers' field of Nalgonda district during 2017-18 and 2018-19.

\section{Materials and Methods}

Farmers are incurring high yield losses due to non-adoption or lack of awareness in correcting nutrient deficiencies in time. Moreover sweet orange crop is being grown in light and shallow soils mostly in the Nalgonda district. To demonstrate the systemic and timely application of micronutrients to increase the crop yields, DAATT Centre, Nalgonda district in Telangana conducted the OFT (On Farm Trial) in farmers field for two years, in each year with three locations and different mandals. In each location of the farmers field observed the yields by providing the micro nutrients from DAATTC, PJTSAU. The OFT conducted in 2016-17 at three locations was Koppole Village of Gurrampode Mandal, Girkabaigudem Village of Nalgonda Mandal and Kurampalli Village of Kangal Mandal. During 2017-18 OFT conducted at Arjalabavi Village of Nalgonda Mandal, Koppolu Village of Gurampadu Mandal and Cherlapally Village of Nalgonda Mandal. In each location in OFT, recommended to farmers to apply micronutrients for correction of deficiencies. The systemic and timely application of micronutrients to improve the better crop growth, flowering and fruit setting. Spraying of micronutrients i.e. $\mathrm{ZnSo}_{4}$ @ 5 gr, $\mathrm{MgSo}_{4} @ 2$ gr, $\mathrm{MnSo}_{4} @ 2$ gr, $\mathrm{FeSo}_{4}$ @2 gr, Borax@1.gr, Ca@6 gr, Urea@10 $\mathrm{g}$ liter of water.

\section{Results and Discussion}

Famers are getting yields of $7600 \mathrm{~kg} / \mathrm{ac}$, Where as $9800 \mathrm{~kg} / \mathrm{ac}$ in OFT. Benefit Cost ratio ( $\mathrm{B}: \mathrm{C}$ ratio) in farmer practice was $1.8: 1$ whereas in case of OFT was 2.6:1during 2016-17 year. In second year, i.e. in 2017-18 the yields of the farmer practice were 7840 $\mathrm{kg} / \mathrm{ac}$ where as in OFT the yields were 9560 $\mathrm{kg} / \mathrm{ac}$. The $\mathrm{B}: \mathrm{C}$ ratio $4.45: 1$ and $5.86: 1$ in farmers practice and OFT respectively. In OFT due to systemic and timely application of micro nutrients improves the yield of Sweet Orange (Fig. 1 and Table 1). 
Table.1 Effect of spraying of micronutrients on yield and B:C ratio of sweet orange in farmers practice and OFT during 2016-17

\begin{tabular}{|c|l|c|c|c|}
\hline S.No. & \multicolumn{1}{|c|}{$\begin{array}{c}\text { Name of the } \\
\text { farmer }\end{array}$} & Village and mandal & $\begin{array}{c}\text { Farmer } \\
\text { Practice }\end{array}$ & $\begin{array}{c}\text { OFT } \\
\text { Trial }\end{array}$ \\
\hline 1. & N. Srinivas Reddy & Koppolu, Gurrampodu & 6740 & 11120 \\
\hline 2. & V. Ramana Reddy & $\begin{array}{c}\text { Girkabai gudem, } \\
\text { Nalgonda }\end{array}$ & 8130 & 10020 \\
\hline 3. & M. Ram Reddy & Kurammpally, Kanagal & 7930 & 8260 \\
\hline & $\begin{array}{l}\text { Avg. Yield } \\
\text { (kg/ac) }\end{array}$ & & $\mathbf{7 6 0 0}$ & $\mathbf{9 8 0 0}$ \\
\hline & $\begin{array}{l}\text { Price @ (Rs./MT) } \\
\text { (Rs.) }\end{array}$ & & $\mathbf{1 3 , 0 0 0}$ & $\mathbf{1 3 , 0 0 0}$ \\
\hline & COC (Rs.) & & $\mathbf{9 8 , 8 0 0}$ & $\mathbf{1 , 2 7 , 4 0 0}$ \\
\hline & Net income (Rs.) & & $\mathbf{5 2 , 6 0 0}$ & $\mathbf{4 8 , 8 0 0}$ \\
\hline & B:C ratio & & $\mathbf{4 6 , 2 0 0}$ & $\mathbf{7 8 , 6 0 0}$ \\
\hline
\end{tabular}

Fig.1 OFT on effect of micro nutrient deficiency on yield and performance of sweet orange (Citrus sinensis), conducted in field of Sri V. Ramana Reddy at Girkabai gudem Village of Nalgonda District

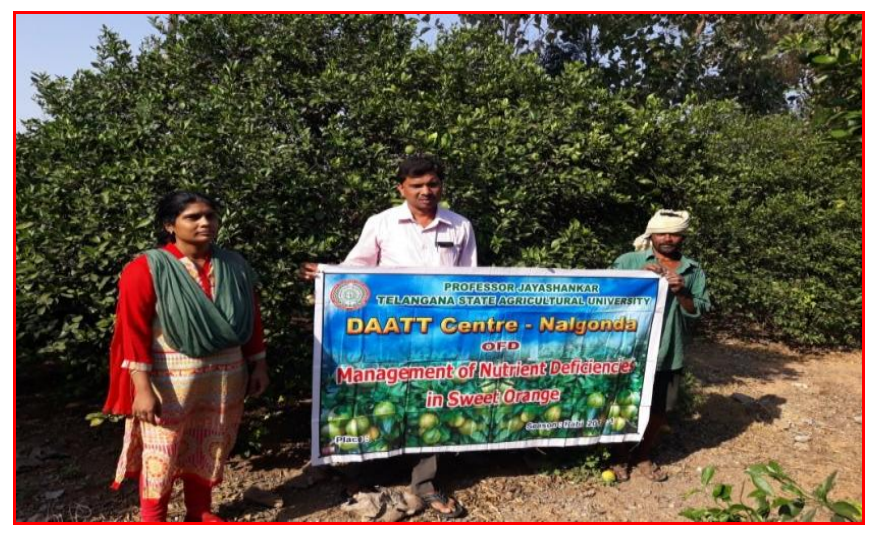

Even though the cost of cultivation was same in two years and yields are also in similar trend but the $\mathrm{B}: \mathrm{C}$ ratio was variable in two years. This is because of high market price in second year i.e. 2017-18. The market price based on demand \& Supply. The market price of Sweet Orange during 2016-17 was Rs.13000/MT. Where as in 2017-18 the market price of Sweet Orange was Rs.30,000/MT. The variability of $\mathrm{B}: \mathrm{C}$ ratio was high between two years due to fluctuation in the market price.

\section{References}

Ashraf M Y, Yaqub J, Akhtar M A, Khan M, Ali-Khan and Abert G. 2012. Improvement in yield and juice quality of kinnow (Citrus deliciosa $x$ Citrus nobilis) through nutrient management. Pakistan Journal of Botany. 44: 259265.

Doberman A and Fairhurst T. 2000. Rice: Nutrients disorder and nutrient management. Potash and Phosphorus, 
Institute of Canada and International Research Institute, Los Baffios, Phillipiness.

Etebu, E., and A. B. Nwauzoma. 2014. A Review on Sweet Orange (Citrus sinensis L Osbeck): Health, Diseases and Management. American Journal of Research Communication, Vol. 2(2).

Horticulture Statistics at a Glance. 2018. Horticulture Statistics Division. Department of Agri. \& Cooperation.

Ibrahim $\mathrm{M}$, Ahmed $\mathrm{N}$, Anwar S A and Majeed T. 2007. Effect of micronutrients on citrus fruit yield growing on calcareous soils. In: Advances in Plant and Animal Boron Nutrition. (Eds) X. U. Fangsen, H. E. Goldbach, P. H. Brown, R. W. Bell, T. Fujiwara, C. D. Hunt, S. Goldberg and L. Shi. Spinger Netherlands. pp 179-
182.

Rodriguez V A, Mazza S M, Martinez G C and Ferrero A R. 2005. $\mathrm{Zn}$ and K influence on fruit sizes of Valencia orange. Revista Brasileira de Fruticulture. 27: 132-135.

Saleem B A, Ziaf K, Farooq M and Ahmed W. 2005. Fruit set and drop patterns as affected by type and dose of fertilizer application in mandarin cultivars (Citrus reticulate Blanco.) International Journal of Agricultural Biology. 7: 962-965.

Shradha Neware, D D Jagtap, Bhagyashri Nadkrni and Miilion paulo S. 2015. Effect of Plant Growth Regulators and Micronutrients on Yield and Quality of Sweet Orange (Citrus sinensis L. Osbeck) cv. Mosambi, Research Journal of Agricultural Sciences. 6(6): 13051308 November - December.

\section{How to cite this article:}

Kola Shailaja and Murali, B. 2020. Effect of Micro Nutrient Deficiency on Yield and Performance of Sweet Orange (Citrus sinensis) in Nalgonda District, Telangana, India. Int.J.Curr.Microbiol.App.Sci. 9(04): 1921-1924. doi: https://doi.org/10.20546/ijcmas.2020.904.228 